\title{
Mutation of the SPS1-encoded protein kinase of Saccharomyces cerevisiae leads to defects in transcription and morphology during spore formation
}

\author{
Helena Friesen, ${ }^{1}$ Rayna Lunz, ${ }^{1,4}$ Steven Doyle ${ }_{r}{ }^{2}$ and Jacqueline Segall ${ }^{1,3,5}$ \\ ${ }^{1}$ Department of Biochemistry, ${ }^{2}$ Department of Microbiology, and ${ }^{3}$ Department of Molecular and Medical Genetics, \\ University of Toronto, Toronto, Ontario, Canada M5S 1A8
}

During sporulation of Saccharomyces cerevisiae, meiosis is followed by encapsulation of haploid nuclei within multilayered spore walls. Completion of the late events of the sporulation program requires the SPS1 gene. This developmentally regulated gene, which is expressed as cells are nearing the end of meiosis, encodes a protein with homology to serine/threonine protein kinases. The catalytic domain of Sps 1 is $44 \%$ identical to the kinase domain of yeast Ste20, a protein involved in the pheromone-induced signal transduction pathway. Cells of a MATa/MAT $\alpha$ sps1/sps1 strain arrest after meiosis and fail to activate genes that are normally expressed at a late time of sporulation. The mutant cells do not form refractile spores as assessed by phase-contrast microscopy and do not display the natural fluorescence and ether resistance that is characteristic of mature spores. Examination by electron microscopy reveals, however, that prospore-like compartments form in some of the mutant cells. These immature spores lack the cross-linked surface layer that surrounds wild-type spores and are more variable in size and number than are the spores of wild-type cells. Despite their inability to complete spore formation, sps1-arrested cells are able to resume mitotic growth on transfer to rich medium, generating haploid progeny. Our results suggest that the developmentally regulated Sps1 kinase is required for normal progression of transcriptional, biochemical, and morphological events during the later portion of the sporulation program.

[Key Words: Saccharomyces cerevisiae; kinase; sporulation; spore wall]

Received July 1, 1994; accepted July 28, 1994.

Sporulation is initiated in the yeast Saccharomyces cerevisiae when MATa/MATa diploid cells are starved for nitrogen in the presence of a nonfermentable carbon source such as acetate (for review, see Esposito and Klapholz 1981). A single round of DNA replication is followed by a lengthy prophase during which homologous chromosomes pair and undergo a high level of genetic recombination. The homologous chromosomes segregate to opposite poles of the nucleus in the meiosis I reductional division. This is followed rapidly by the mitosis-like meiosis II division in which sister chromatids segregate from each other. In yeast, the nucleus remains intact throughout meiosis. The intranuclear segregation of the chromosomes generates four bulges in the nucleus, one beside each spindle pole body (for review, see Byers 1981). Prospore walls begin to form at the spindle pole bodies and expand to encapsulate the haploid meiotic products present in each nuclear lobe. Maturation of

\footnotetext{
${ }^{4}$ Present address: Ernst and Young, Pittsburgh, Pennsylvania 15219 USA.
} ${ }^{5}$ Corresponding author. the spore walls then generates the four spores that are retained within the ascal sac.

A number of different approaches have been used to identify genes involved in sporulation-specific events. Various genetic screens have led to the isolation of mutants that are defective in meiotic recombination, homolog pairing, segregation of chromosomes, and spore formation (for examples, see Esposito and Esposito 1969, 1974; Tsuboi 1983; Rockmill and Roeder 1988; Hollingsworth and Byers 1989; Briza et al. 1990b; Malone et al. 1991). Cloning and characterization of a large number of the genes identified in these studies have almost invariably revealed that they are expressed preferentially in sporulating cells (for review, see Mitchell 1994). In contrast, many of the sporulation-specific genes that were identified on the basis of their expression pattern (Clancy et al. 1983; Percival-Smith and Segall 1984; Gottlin-Ninfa and Kaback 1986; Law and Segall 1988; Bishop et al. 1992, Coe et al. 1992) do not appear to have an essential role in the sporulation program /Garber and Segall 1986; Gottlin-Ninfa and Kaback 1986; Percival- 
Smith and Segall 1986; Law and Segall 1988; Kao et al. 1989; Kallal et al. 1990; Muthukumar et al. 1993|. SPS1 is one of the few sporulation-specific genes isolated in a differential hybridization screen (Percival-Smith and Segall 1984) that was found to be required for spore formation (Percival-Smith and Segall 1986). As reported here, determination of the sequence of SPS1 revealed that the gene encodes a protein with homology to serine/ threonine protein kinases. Characterization of the phenotype of sps1/sps1 cells indicates that the SPS1-encoded kinase is required for spore wall formation.

\section{Results}

Sps1 is a putative serine/threonine protein kinase

The identification of SPS1 as a gene that is preferentially expressed midway through the sporulation program of $S$. cerevisiae (Percival-Smith and Segall 1984) suggested that its product might participate in a sporulation-specific event. We found previously that mutation of SPS1 blocks spore formation (Percival-Smith and Segall 1986). To determine whether the deduced amino acid sequence of Sps1 might provide some clue as to its role, we determined the nucleotide sequence of the gene. The sequence revealed a single long open reading frame $(O R F)$ of $1470 \mathrm{bp}$ (Fig. 1). The predicted 490 -amino-acid protein encoded by this ORF has a calculated molecular weight of 55,668. A comparison of the predicted Spsl protein with proteins in the National Center for Biotechnology Information data base revealed that the Sps1 sequence from residue 18 to 272 was similar to the catalytic domain of protein kinases. Sps 1 contained all of the invariant amino acids identified by Hanks (1991) in a comparison of 100 serine/threonine protein kinases. The amino acid sequences of subdomains VIb and VIII, which appear to determine the specificity of the kinase, suggested that Spsl was a serine/threonine protein kinase /Hanks et al. 1988). The carboxy-terminal nonkinase domain of Sps1 had no significant similarity to other proteins in the data base. A BLAST search (Altschul et al. 1990) of the National Center for Biotechnology Information data base revealed that the proteins with the highest sequence identity with the kinase domain of Sps1 were the yeast kinase Ste20, which is a member of the mitogen-activated protein (MAP) kinase pathway involved in pheromone response in yeast; $\mathrm{p} 65^{\mathrm{PAK}}$, a kinase from rat brain that is activated by the GTP-bound form of a small Rasrelated protein and that is postulated to be involved in response of the cytoskeletal network to extracellular signals (Manser et al. 1994); a human B lymphocyte protein kinase (Katz et al. 1994); and an uncharacterized yeast kinase (GenBank accession number X69322). The primary sequence of the kinase domain of Sps1 was $44 \%$ and $42 \%$ identical with the sequence of the kinase domains of Ste20 and p65 ${ }^{\text {PAK }}$, respectively (Fig. 2). The similarity in sequence between Sps1 and a member of a MAP kinase activation pathway raises the possibility that Sps 1 might be involved in a signal transduction event during sporulation.

\section{SPS1 is expressed as meiosis is nearing completion}

To determine the time at which Sps1 serves its role in sporulation, we correlated the time of expression of the SPS1 gene in our standard wild-type strain with the major events of sporulation. The temporal pattern of expression of SPS1 was determined by Northern blot analysis of RNA prepared from cells that had been harvested at various times after transfer to sporulation medium (Fig. $3 \mathrm{~A})$. Completion of the meiotic divisions was assessed by examination of aliquots of $4^{\prime}, 6^{\prime}$-diamidino- 2 phenylindole (DAPI)-stained cells; in this procedure, the fluorescent visualization of DNA allows chromosome segregation to be monitored (Fig. 3B). The appearance of binucleate cells and tetranucleate cells is considered to mark the completion of meiosis I and meiosis II, respectively. Spore formation was monitored by phase-contrast microscopy (Fig. 3B,D). This analysis indicated that SPS1 transcripts were first detectable $6 \mathrm{hr}$ after transfer of cells to sporulation medium (Fig. 3A). Accumulation of transcript was maximal at $8-10 \mathrm{hr}$ of sporulation (Fig. 3A); at this time the sporulating cells were beginning to complete meiosis I as assessed by the appearance of binucleate cells (Fig. 3B). As tetranucleate cells began to accumulate between 10 and $13 \mathrm{hr}$, the level of SPS1 transcripts was beginning to decline (Fig. 3A,B). The level of SPS1 transcripts continued to decline during the period of spore formation between 12 and $16 \mathrm{hr}$ (Fig. 3A,B).

We also compared the time of expression of SPS1 with the time of expression of two other sporulation-specific genes, HOP1 and DIT1. HOP1, which is is required for pairing of homologous chromosomes (Hollingsworth and Byers 1989; Hollingsworth et al. 1990), is expressed coincidentally with a large number of other meiotic genes such as SPO11 (Atcheson et al. 1987), RED1 (Thompson and Roeder 1989), and REC114 (Pittman et al. 1993), which encode products required for successful completion of meiosis (for review, see Mitchell 1994). DIT1, which is expressed just prior to spore formation, is required for deposition of the outermost layer of the spore wall (Briza et al. 1990b). We found that HOP1, SPS1, and DIT1 were turned on sequentially (Fig. 3A); expression of HOP1 preceded expression of SPS1 by $\sim 2 \mathrm{hr}$, and expression of DIT1 began $2 \mathrm{hr}$ after the SPS1 gene had been turned on. This sequential pattern of gene expression was consistent with previous observations (Briza et al. 1990b; Mitchell et al. 1990; Smith et al. 1990).

\section{SPS1 is not essential for meiosis}

The observation that SPS1 was expressed as meiosis was nearing completion suggested that SPS1 was required for a postmeiotic event. We found that cells of a MATa/ MATa $\Delta$ sps1/Asps1 strain successfully completed the meiotic divisions. Generation of the $\Delta$ sps 1 allele for this strain was achieved by replacement of the 5 ' region of SPS1 with a DNA fragment containing TRP1 (see Materials and methods); no SPS1-derived transcripts could be 

GASCTCCATT OCTAAOTCTT CTCAMATTT GATETCOCCA ACAAMCITAT TMACANTCCA TAAGTCTTTA AMATM 211 GACACATAMA AMCGAMAAG ACACAMATTC CATTTTTYTT TTPTGAOCOG AMMGAMTCAC ACTACTTTCT TCTr 351

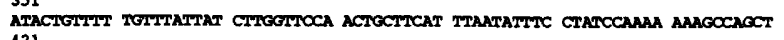
421 491 561 $601 / 1$

ATE GaA AOC MAA GaA ATA TCA ATT AOG TCA AGA ACC OCT CCA TOG ANG CTA TAT TOC ATC wat Glu ser bys Glu Ile sar Ile Arg Ser Arg Thr Pro pro ser Lyb Lau Tyr Ser Ile $661 / 21$

CAA TCA TGT ATT GGC AGA GGT AAC TTT GGT GAT GIG TAT AAA OCA GTG GAT ACA GTT ACG GIn Sar Cys Ile Gly Arg Gly Asn Phe Gly Asp Val TyY LYS Ala Val Asp Arg Val Thr

CAA GA ATT GTG GCA ATT AAG OTG GTC AAC CTG GAG CAT TOC CAC GAA GAC ATT GAN CTG Gin Glu the val ala Ile Lys Val Val Asn Leu Glu His Ser Asp Glu Asp Ile glu Lou $781 / 61$

TTA GCA CAG GAM ATT TTT TIT CTG GOG GAA TTG AMA TCT CCT CTS ATT ACA AAC TAT ATP Lau Ala Gln Glu tle phe phe leu ala glu Leu Lys Ser Pro tau Ile Thr Aan tyr Ile $841 / 81$

OCA ACA ATG TTA GAA CAT GTC TCT ATG TGG ATT GTC ATG GAA TAT Tœ GOC OCA COA TCA Ala Thr Met Leu Glu Aap val Ser tro Ile val hat Glu Tyr cys Gly Gly Gly Ser

TOT TCA GAT TTA CTG AAG CGA AGT TAC OTC AAC GGT TTG CCT GAA GA AM GIT TCC TTC Cys Sar Asp Leu Lau Lys Arg Ser Tyr val Asn Gly Iou Pro Glu Glu Lys val ser phe ATT ATT CAT GAA GTC ACC TIG GET TTG AAA TAC CTG CAT GAG CAA AOG AAA ATT CAT CG Ile Ile his Glu val thr Leu gly Leu lys tyr Leu his Glu Gln Arg lys t le his arg $1021 / 141$

GAT ATC AMA GCA GCT AAT ATT TTA CTA AAT GAA GAA GGT ATG GTT AAG TTG GGT GAT TTC

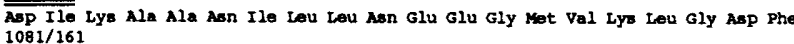

GGA GTA AGT GGC CAC ATT CGT TCC ACT TTG AAA AGG GAC ACT TTT GTA GGA AOG CCG TMT Gly val Ser Gly his Ile arg Ser Thr Leu Lys Arg Aop Thr phe val Gly thr pro tyr $1141 / 181$

TGG ATG GCT COG GAA GTT GTT TGC TOC GAA GTT GAT OGG TAT AAT GAG AAA GCA GAT ATA Trp Net Ala Pro Glu val val Cys Cys Glu val asp Gly Tyr Asn Glu Lys ala Asp Ile $1201 / 201$

2GG TOC TTE GOT ATC ACC AOC TAT GAG TTA CTC AAG OGC TTA OCC CCA TTA TCT AAA TA

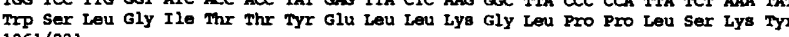
$1261 / 221$

GAT CCT ATG AaA GTT ATG ACT AAC TTTA CCA AaA AGG AaG CCT OCA AaA TTA CAA GCT OCC

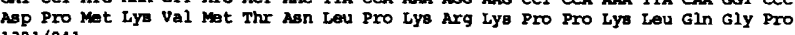
$1321 / 241$

Phe Ser Asp Ala Ala tys Asp pho Val Ala Gly Cys Leu Val Lys Thr pro Ala Asp Arg TTT TCG GAT GCA GCA AAG GAT TTC GTA GCT OOT TOT CTT GTT AAA ACA CCT GCT GAT OCG $1381 / 261$

OCA TCG OCA TAT AAC TTG TTA TCA TTT GAM TTT GTT AAG AaT ATC AOC ATA AOG MAC TTG Pro Ser Ala Tyr Asn Leu Leu Ser phe Glu Phe Val Lys Asn Ile Thr Ile thr Asn Leu

1441/281 Lys Ser Aap val Asp teu Ile Lys Gln Lys Lys Val Gln Glu Arg Tyr Thr Lys Val pro $1501 / 301$

AAA TAC CCT CTT CAA AAT COC TTG TAT AAR AAC ACC AAC ACA GTG AOG OGA AAG GAA TTT Lys Tyr Pro Leu Gin Asn Arg Leu Tyr Lys Asn Ser Asn Thr Val Arg Gly Lys Glu phe $1561 / 321$

TGG AAT TTT GAA TCG ACA AGA CTA AOC ACA ACA CAA ATT TOC AAA GAG GAA TTA TCT COC TrP Asn phe Glu Ser thr Ang Leu Ser Thr Thr Gln Ile ser LyB Glu Glu Leu Ser Pro $1621 / 341$

Jle Thr Gln Asp Ser Pro Thr Ser Ser Leu Aan Mat Glu Ser Pro Tyr Leu Leu His Gly ATT ACA CAA GAC TCT OCA ACA TCA TCT TTA AAT ATG GA AGT OCT TAT TTA CTT CAT OOG $1681 / 361$

CAA ACT GTA ACG CCG ATA AOC AAC CCA AGT TCT TCA TCA TTT AGA AMA TGT AOG CAA CCA Gin thr val thr pro Ile Thr Asn pro Ser ser ser ser phe arg Lys Cyg Thr gln Pro $1741 / 381$

GTT TTC GAG CTT GAT TCA GGA ATG GAT ATA GAT TCA OSC TOC CCA AAT GCT CAA GCA GAG Val phe Glu Leu Asp ser Gly tet Asp ile Asp Ser Gly Cys pro asn Ala Gin Ala glu $1801 / 40$

Thr Glu Ile val Pro lou ser Asn His Asn Lys Lys His Lys Lys Asn Asp Ile Gln Ala ACC GAA ATA GTT CCT CTC TCT AAT CAT AAT AAG AAG CAT AAM AAG AAC GAT ATT CAG OCG ACC GAA

TTG AAG ATA GAA AAG TTT GAC TAC TTG AAA AAC ATT OTR TCT CAT ATT CTC AAC ACA ATG

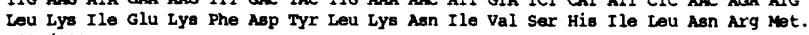
$1921 / 441$

TAT Gat CGT GOG CGC GAC GAT GAA ACA AGa AaA TAC GTA Aat GAA ATG TTA Aag CAA TTC Tyr Asp Arg Ala Arg Asp Asp Glu Thr Arg Lys Tyr val Asn Glu Met Leu Lys Gin phe $1981 / 461$

ATT AAA ACT GAG OCA AAC GTT CCT OGA TTT AAT GAG GTT TTT ATA GAA GAG ATC TCA CTA Ile Lye thr Glu Ala Aan val pro gly phe Aan glu val phe Ile Glu glu Ile ser Lou $2041 / 481$

AGA ATT GAA GCA ATA AAG AAA GGA TTC GTT TAA

AaA Ile Glu Ala Ile Lys Lys Gly phe Val TER

Figure 1. Nucleotide sequence of the SPS1 gene. The nucleotide sequence of the nontranscribed strand of the SPS1 gene is given with the predicted translation product indicated below the DNA sequence. Throughout the translated region, the first number refers to the nucleotide position relative to a SacI site $600 \mathrm{bp}$ upstream of the initiator ATG; the second number refers to the position of the codon relative to the predicted initiator ATG. The ClaI recognition site beginning at nucleotide 302 and the EcoRV recognition site beginning at nucleotide 1021 , which were used in the construction of the $\Delta s p s 1: \because T R P 1$ allele, are doubly underlined. The BgIII site beginning at nucleotide 2030, which was used in the construction of the sps $1:: U R A 3$ allele, is underlined. The sequence beyond this BglII site is from Percival-Smith and Segall (1986). detected in the MATa/MATa $\Delta s p s 1 / \Delta s p s 1$ strain in sporulation medium (data not shown). Examination of DAPI-stained cells by fluorescence microscopy indicated that both meiosis I and meiosis II occurred at approximately the same times in the mutant cells as in wildtype cells with the majority of multinucleate cells appearing between 8 and $12 \mathrm{hr}$ (Fig. 3B,C). In various experiments, we found that meiosis I occurred in the mutant cells with an efficiency of $80-100 \%$ of that in wild-type cells (Fig. 3B,C; data not shown) and meiosis II occurred with an efficiency of $60-75 \%$ of that in wildtype cells (Fig. 3B,C; data not shown). Although the SPS1 mutant cells reproducibly showed a reduction in the efficiency of the second meiotic division, the majority of the mutant cells that had completed meiosis I went on to complete meiosis II but were then unable to form spores as assessed by phase-contrast microscopy (Fig. 3C,E; Percival-Smith and Segall 1986). We found that a portion of the mutant cells that had been in sporulation medium were unusually large (Fig. 3E). The mutant cells that had been in sporulation medium also lacked the fluorescence and ether resistance that is attributed to deposition of a dityrosine-containing macromolecule on the outer surface of the spore (data not shown; Briza et al. 1990a,b). We therefore concluded that the major effect of the absence of the SPS1 gene product was to prevent proper packaging of spores.

\section{Haploid progeny can be generated from sps1. arrested cells}

As mentioned above, DAPI is a fluorescent dye allowing visualization of DNA; thus the segregation of homologous chromosomes to opposite poles during meiosis I leads to the appearance of cells that are referred to as binucleate, and the subsequent segregation of sister chromatids to opposite poles during meiosis II leads to the appearance of cells that are referred to as tetranucleate. The nuclear envelope, however, remains intact during yeast meiosis; at the end of meiosis II, the extended and lobulated nucleus of the so-called tetranucleate cell contains a haploid complement of chromosomes in each nuclear lobe. Compartmentalization of the haploid genomes is thought to be dependent on formation of prospore walls around the nuclear lobes. The prospore envelope, which pinches off the haploid nuclei and traps some cytoplasmic material, then serves as the scaffold for deposition of spore wall-specific material (Moens 1971; Moens and Rapport 1971). Upon germination, the four spores present within the ascal sac are released and the growth of the individual spores gives rise to haploid progeny.

To test for compartmentalization of the meiotic products in sps1-arrested cells, we assessed the ploidy of progeny derived from these cells. If the meiotic nucleus generated in an sps1/sps1 cell did undergo compartmentalization, we anticipated that it would be possible to recover haploid progeny. First, we determined whether sps1-arrested cells could resume mitotic growth (Fig. 4). We found that the viability of sps1/sps1 cells that had been in sporulation medium for $24 \mathrm{hr}$ was $\sim 80 \%$ that of wild-type sporulating cells (Fig. 4). We then assessed the 

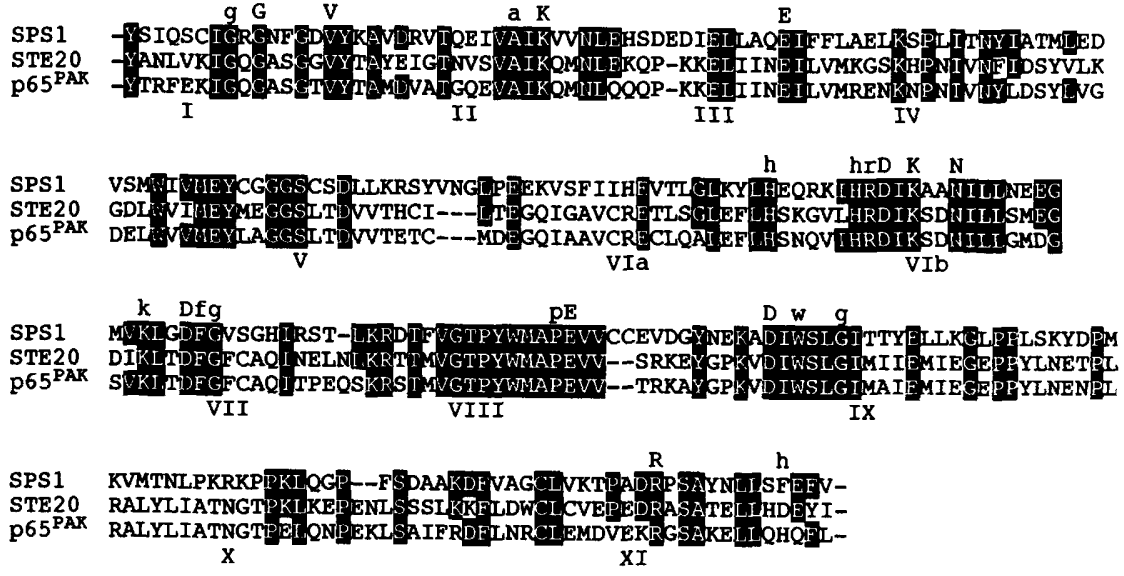

Figure 2. Alignment of the kinase domain of Sps1 with the corresponding domains of Ste 20 and $\mathrm{p} 65^{\mathrm{PAK}}$. The deduced sequences of the kinase domains of Sps1, Ste20 (Leberer et al. 1992; Ramer and Davis 1993), and $065^{\text {PAK }}$ (Manser et al. 1994) have been aligned by eye, guided by the alignments generated by the BLAST program (Altschul et al. 1990). The positions of gaps, introduced to maintain alignment and denoted by dashes, were guided by the comparisons of Hanks (1991). The sequences of the kinase domains of Sps1, Ste20, and p65 ${ }^{\text {PAK }}$ begin at residues 18,620 , and 269 , respectively. Amino acids that are identical between Spsl and Ste20, between Spsl and p65 ${ }^{\mathrm{PAK}}$, or among all three proteins are highlighted. The top line denotes amino acids that are invariant (uppercase) or almost invariant (lowercase) in a comparison of the catalytic domains of 100 serine-threonine protein kinases (Hanks 1991). Roman numerals indicate the 12 kinase subdomains identified by Hanks and Quinn (1991).

DNA content of the progeny derived from sporulating cells by flow cytometry. FACS analyses were first performed on exponentially growing cultures of haploid SPS1 cells, diploid SPS1/SPS1 cells, and diploid sps1/ sps1 cells. These control scans showed a typical distribution of cells with a greater portion of the population being in $G_{2}$ than in $G_{1}$ (Fig. 5A-C). Similar scans were then performed on cells that had been incubated in sporulation medium for $21 \mathrm{hr}$, diluted, and grown in liquid rich medium for $21 \mathrm{hr}$. In the scan of wild-type diploid cells subjected to this regimen, germination and growth of haploid spores were visualized by the appearance of a peak of $G_{1}$ cells with a $1 N$ DNA content (Fig. $5 D$ ). The peak of $G_{2}$ cells with a 4N DNA content in this scan indicated that a portion of the cells in this population were diploids. Most of these diploid cells were presumably derived from cells that did not enter the meiotic pathway on transfer to sporulation medium. It is possible that these nonsporulating cells resumed growth prior to germination of spores, accounting for the relatively low portion of haploid cells in the population. FACS analysis of a culture derived from sps1-arrested cells returned to growth medium revealed a minor population of haploid cells, approximately one-fifth to one-third the portion present in the population derived from wild-type sporulating cells (Fig. 5E; data not shown). On the basis of this analysis we concluded that the sps1-derived cells could generate haploid progeny, although less efficiently than did wild-type cells. The reduced level of haploidization can be accounted for in part by the fact that the mutant cells completed meiosis less efficiently than did wild-type cells.

As an alternative approach for detecting haploid progeny of sps1-arrested cells, we tested for segregation of recessive drug-resistance markers. In this experiment, SPS1/SPS1 CAN ${ }^{\mathrm{s}} 1 / \mathrm{Can}^{\mathrm{r}} 1 \mathrm{CYH}^{\mathrm{s}} 2 / \mathrm{cyh}^{\mathrm{r}} 2$ and sps1/sps1 $C A N^{\mathrm{s}} 1 / \mathrm{Can}^{\mathrm{r}} 1 \mathrm{CYH}^{\mathrm{s}} 2 / \mathrm{cyh}^{\mathrm{r}} 2$ cells, which are sensitive to canavanine and cycloheximide, were incubated in sporulation medium for $21 \mathrm{hr}$ and then plated on rich medium and tested for resistance to cycloheximide and canavanine. One-half of the haploid progeny of wild-type cells would be expected to be resistant to each drug; as we were testing colonies derived from asci, each colony would be expected, in the absence of sib-matings, to contain drug-resistant cells. We found that $53 \%$ and $57 \%$ of the colonies derived from wild-type cells that had been in sporulation medium contained cells that were resistant to cycloheximide and canavanine, respectively. Nineteen percent and $15 \%$ of the colonies recovered from sps1/sps1 cells that had been in sporulation medium were resistant to cycloheximide and canavanine, respectively. The sps $1 c^{2} h^{\mathrm{r}} 2$ and $s p s 1$ can $^{\mathrm{r}} 1$ cells appeared to be derived by haploidization, as most of the dnug-resistant cells were also maters (data not shown). In summary, both this genetic analysis and analysis of DNA content by flow cytometry indicated that sps1-arrested cells could generate haploid progeny on resumption of growth, although less efficiently than did wildtype sporulating cells.

\section{Aberrant spore formation in sps $1 /$ sps 1 cells}

To assess the sporulation defect of sps1/sps1 cells in more detail, we used electron microscopy to examine cells that had been in sporulation medium for $21 \mathrm{hr}$. A typical wild-type ascus is depicted in Figure 6A. The outermost surface of the spore wall (Fig. 6C), which appears as a very thin, osmiophilic layer, consists of a crosslinked insoluble macromolecule containing a large amount of dityrosine (Briza et al. 1990a,b). This layer, which is responsible for the resistance of spores to degradative enzymes and organic solvents (Briza et al. 1990b) is closely associated, perhaps by covalent linkages, with an underlying chitosan layer (Briza et al. 19881, which appears as a more diffuse osmiophilic layer. The innermost layers of the spore wall are similar in composition to the vegetative cell wall and often appear 
A

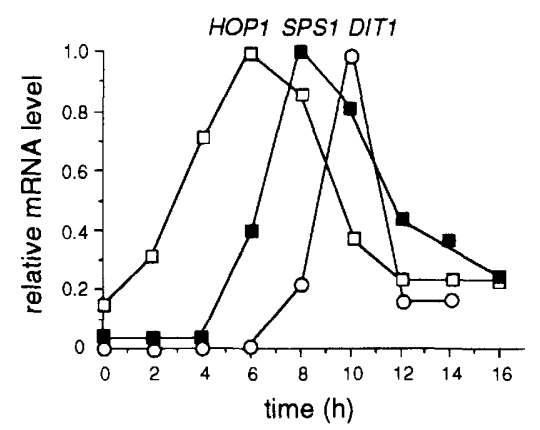

B

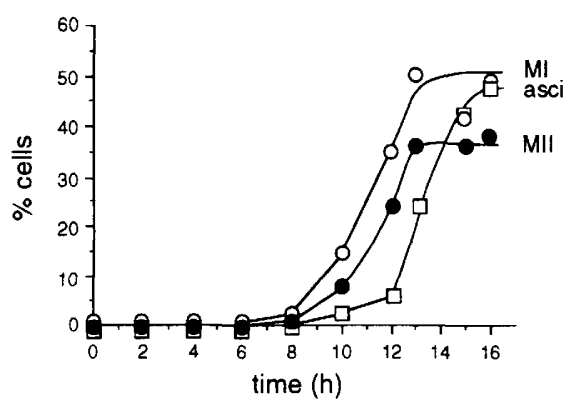

C
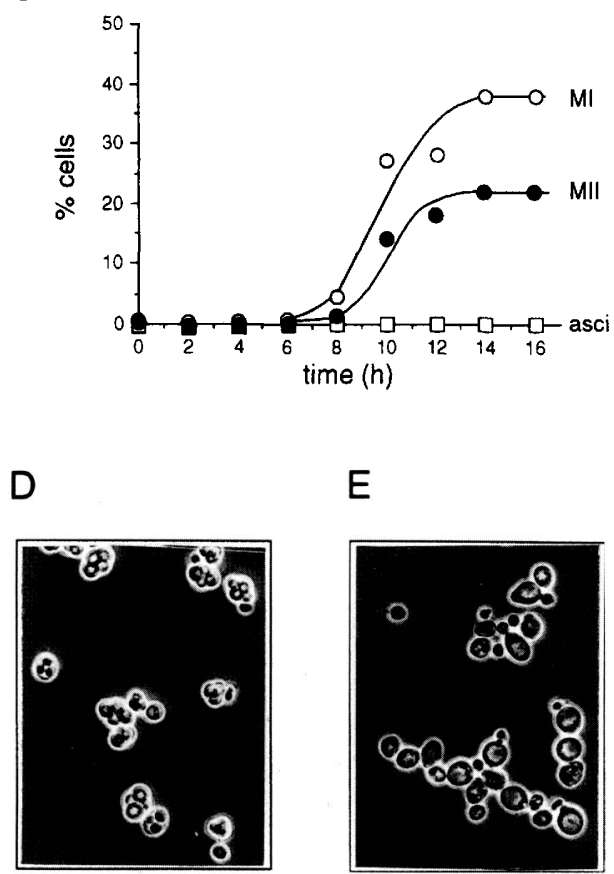

$E$

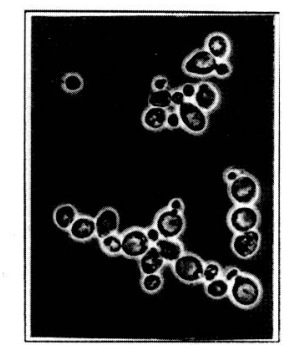

as a single electron-transparent layer (Katohda et al. 1984; Briza et al. 1988).

Examination of sps1/sps1 cells that had been in sporulation medium for $21 \mathrm{hr}$ revealed that many of the mutant cells could elaborate prospore-like compartments. There were generally only one or two of these compartments per cell, and they were generally smaller than were wild-type spores. Some of the compartments were very similar in appearance to a prospore at an early stage
Figure 3. The SPS1 gene is expressed at the end of meiosis and is not required for completion of the meiotic divisions. $(A)$ RNA was prepared from aliquots of wild-type cells (LP-HT) taken at various times after transfer to sporulation medium. The RNA was denatured, separated by electrophoresis through a $1.5 \%$ agarose-formaldehyde gel, and transferred to a nylon membrane. The blot was hybridized sequentially with radioactively labeled probes containing the HOP1 gene, the SPS1 gene, the DIT1 gene, and the PYK1 gene (see Materials and methods). Hybridization was quantified by PhosphorImager, and the relative amount of each sporulation-specific RNA is given as a ratio of the amount of that RNA to the amount of PYK1 RNA at each time point. This ratio was normalized by giving the highest ratio for each sporulation-specific RNA a value of 1 . (D) HOP1; (D) SPS1; (O) DIT1. (B) Samples of cells from the same sporulating culture that was analyzed in $A$ were fixed, stained with DAPI, and examined by fluorescence microscopy to determine the percentage of cells that had completed meiosis $I(O)$ or meiosis II (O). Cells that appeared binucleate, trinucleate, or tetranucleate by DAPI staining were considered to have completed meiosis I. Cells that appeared trinucleate or tetranucleate were considered to have completed meiosis II. Cells were examined by phase-contrast microscopy to monitor ascus formation ( $\square$ ). (C) Samples of MATa/MATa $\Delta$ sps1/ $\Delta$ sps1 cells (Y26) were examined as described for $B .(D)$ Photograph of wild-type sporulated cells $(\mathrm{Y} 30)$ viewed by phase-contrast microscopy. A high proportion of cells have formed asci with a triad or tetrad of spores visible. (E) Photograph of sps1/sps1 cells (Y26) viewed by phase-contrast microscopy. No asci are visible.

of development, consisting of a nucleus surrounded by a double membrane. Other compartments had the appearance of prospores arrested just prior to spore wall maturation; at this stage, electron-transparent spore wall material has been deposited within the double membrane

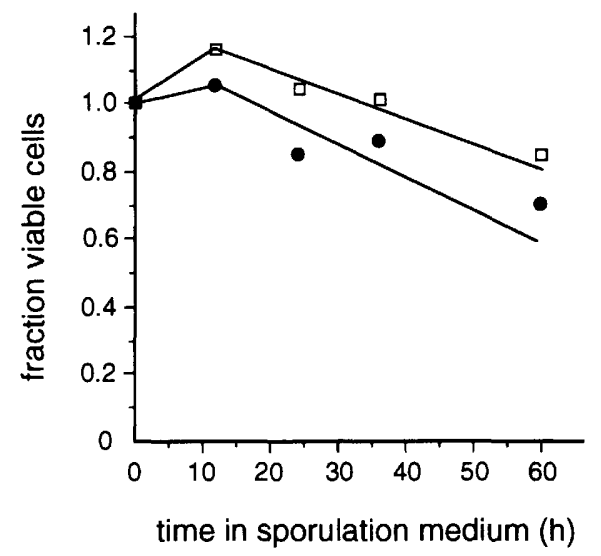

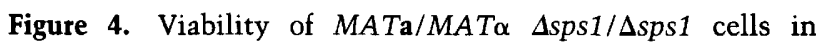
sporulation medium. Samples of MATa/MAT $\alpha P S 1 / S P S 1$ cells

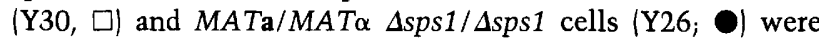
taken at various times after transfer to sporulation medium. The aliquots were vortexed, diluted, and plated on YPD. For each strain, the number of viable cells is expressed as a ratio of the number of colony-forming units (cfu) at a given time after transfer of cells to sporulation medium to the number of cfu at the time of transfer to sporulation medium. In this experiment, the efficiency of ascus formation was $54 \%$ for strain Y30. Strain Y26 generated no asci. 

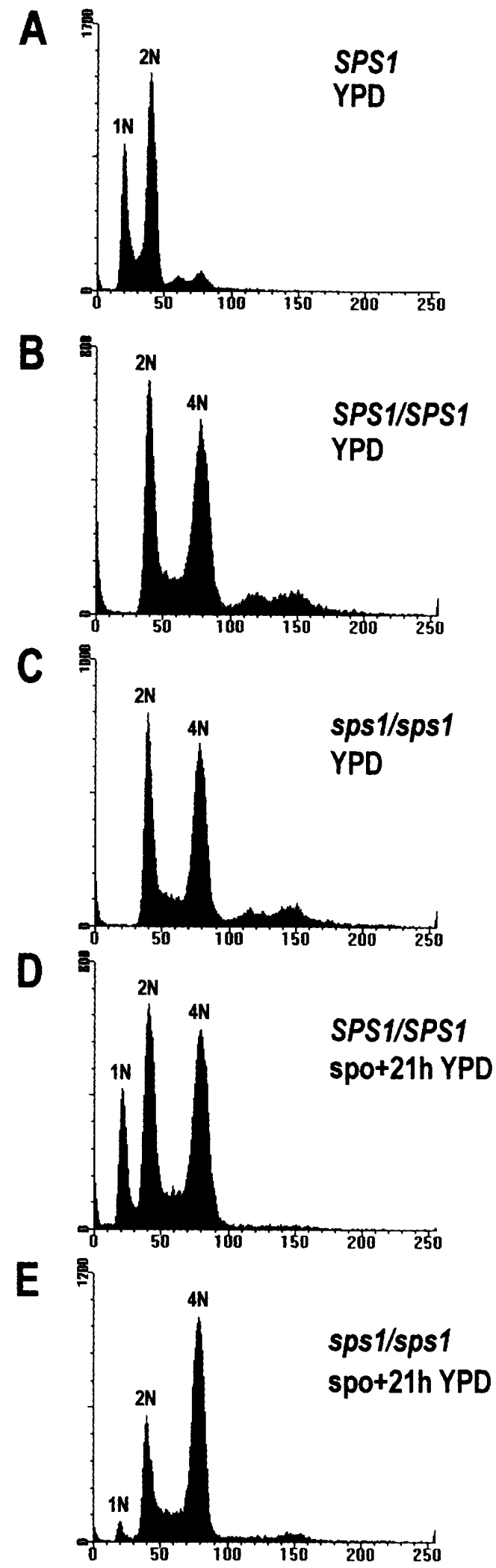

(for descriptions of spore wall development, see Lynn and Magee 1970; Moens 1971; Guth et al. 1972; Beckett et al. 1973; Illingworth et al. 1973). Spore-like compartments that differed in appearance, as well as unenvel-
Figure 5. FACS analysis reveals that $s p s 1$-arrested cells generate haploid progeny. Cells were fixed and stained with propidium iodide prior to analysis in a Becton Dickinson FACScan. (A) Scan of haploid SPS1 cells (W3031B) grown in YPD. The peaks of cells marked $1 \mathrm{~N}$ and $2 \mathrm{~N}$ represent cells in $\mathrm{G}_{1}$ and $\mathrm{G}_{2}$ of the cell cycle, respectively. (B) Scan of diploid SPS1/SPS1 cells (Y30) grown in YPD; (C) scan of diploid sps1/sps1 cells (Y26) grown in YPD. The peaks of cells marked $2 \mathrm{~N}$ and $4 \mathrm{~N}$ represent cells in $\mathrm{G}_{1}$ and $\mathrm{G}_{2}$ of the cell cycle, respectively. $(D)$ Scan of SPS1/SPS1 cells (Y30) that had been incubated in sporulation medium for 21 $\mathrm{hr}$ and then grown in YPD for $21 \mathrm{hr}$. The efficiency of sporulation of these cells was $\sim 60 \%$. The peak of cells marked $1 \mathrm{~N}$ represents haploid cells in $\mathrm{G}_{1}$. These cells were derived from spores that had germinated and had begun to grow vegetatively. The peak of cells marked $2 \mathrm{~N}$ represents both haploid cells in $\mathrm{G}_{2}$ and diploid cells in $G_{1}$. The diploid cells are cells that failed to sporulate. The peak of cells marked $4 \mathrm{~N}$ represent diploid cells in $\mathrm{G}_{2}$. $(E)$ Scan of sps1/sps1 cells (Y26) that had been incubated in sporulation medium for $21 \mathrm{hr}$ and then grown in YPD for $21 \mathrm{hr}$. No asci were seen in these cells after $21 \mathrm{hr}$ in sporulation medium. The graphs depict relative DNA content ( $x$-axis) vs. cell number ( $y$-axis).

oped nuclei, could be found within a single cell. In some instances, it was not clear whether the compartment contained a nucleus.

Electron micrographs of representative sps1-arrested cells are presented in Figure 6. The cells in Figure 6, E and $F$, contained very immature prospore-like compartments enclosed by a double membrane. In one case, the prospore delimiting membranes had not yet enveloped a presumptive nucleus completely (Fig. 6G). The cells presented in Figure 6, H and I, contained more mature prospore-like compartments. Cell wall material had been deposited between the double membrane leading to an electron-transparent layer. The two innermost layers of the wall could be seen in the prospore shown in Figure 6J. As has been noted previously for cells in the early stages of spore formation, the mutant cells contained many small electron-transparent vesicles (Beckett et al. 1973; Illingworth et al. 1973) and the prospore-like compartments were surrounded by endoplasmic reticulum (Lynn and Magee 1970) (Fig. 6G,J). Figure 6B presents an example of a mutant cell containing one of the more mature spore-like compartments that we observed in the mutant population. The spore wall appeared to lack the outer chitosan and the dityrosine-containing layers present in wild-type spores (Fig. 6D). In summary, SPS1 mutant cells were able to divide their postmeiotic nucleus into distinct compartments. In some instances, the early stages of spore wall development appeared normal but spore wall maturation did not occur.

SPS1 is required for normal expression of late sporulation-specific genes

Several classes of temporally distinct sporulation-specific genes, referred to as early, middle, mid-late and late, are sequentially expressed as the sporulation program proceeds (for review, see Mitchell 1994). Expression of middle SPS genes, which include SPS1, SPS2, and SPS4 (Percival-Smith and Segall 1984, 1986; Garber and Segall $1986 \mid$, is followed by expression of the mid-late genes, DIT1 and DIT2, which are essential for formation of the 
Figure 6. Electron microscopy of sporulated SPS1/SPS1 and sps1/sps1 cells. (A) A typical ascus showing three spores is depicted for the wild-type strain Y30 (SPS1/ SPS1). Note that electron micrographs of four-spored asci rarely show more than three spores within one plane as a result of the tetrahedral arrangement of the spores. (B) A sporulated cell from strain Y26 (sps1) sps1) showing one relatively mature prospore-like compartment (top), one immature prospore-like compartment (mid$d l e$ ), and one unencapsulated nucleus (bottom). (C) A portion of the wall of two of the spores present in the ascus of $A$ is depicted at higher magnification. The arrowheads refer to d, the outermost, very thin and osmiophilic dityrosine-containing layer of the spore wall; c, the underlying, diffuse, and osmiophilic chitosan layer; and $i$, the innermost, electron transparent layers. $|D|$ Higher magnification view of the boxed region of the mutant sps1/sps1 cell depicted in $B$ showing the envelope surrounding the prospore-like compartments. Note the absence of a well-defined outer membrane and the absence of the chitosan and dityrosine-containing layers. $(E, F)$ Examples of sps1/sps1 cells containing relatively immature-looking prospore-like compartments. (G) Higher magnification view of the prospore-like compartment seen at the top, left of the cell shown in $F$. The sporedelimiting membrane has not completely enclosed its contents. $(H, I)$ Examples of sps1/sps1 cells containing relatively mature-looking prospore-like compartments. (J) Higher magnification view of the prospore-like compartment seen in the cell of $I$. (V) vacuole; (N) unencapsulated nucleus; (arrowheads) prospore-like compartments. Bars, $400 \mathrm{~nm}$.
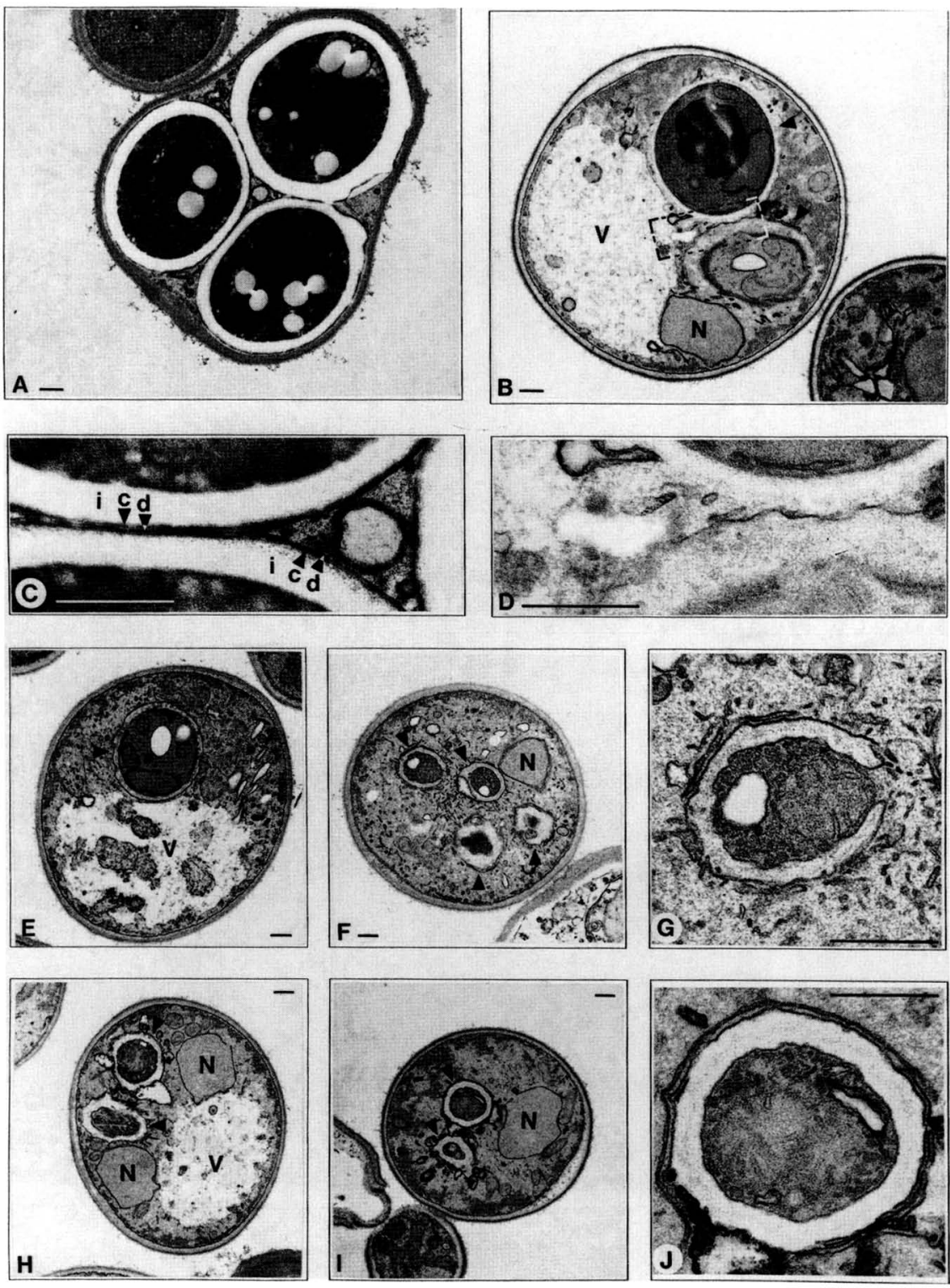

outermost layer of the spore wall (Briza et al. 1990b). The late SPS genes SPS100 and SPS101 are activated $\sim 4 \mathrm{hr}$ after the DIT genes are turned on. The SPS100 gene has been shown to contribute to the development of the ether resistance that is a characteristic of mature spores (Law and Segall 1988). To determine whether mutation of the SPS1 gene affected the pattern of sporulation-specific gene expression, we monitored accumulation of transcripts of various genes in wild-type cells and in sps1/sps1 cells in sporulation medium by Northern blot analysis. The expression of SPS2 and SPS4, which coincides with expression of SPS1, was similar in both strains (Fig. 7A,B). DIT1 transcripts, however, accumulated to a much higher level in the sps1/sps1 strain than in the wild-type strain (Fig. 7C), suggesting that the turning off of the DIT1 gene was delayed in the absence of
Spsl. It is also possible that the DIT1 promoter was more active or that DIT1 transcripts were more stable in the absence of Sps1. Another dramatic effect of mutation of SPS1 was seen on examining expression of the SPS100 and SPS101 genes. In wild-type cells, transcripts corresponding to these genes accumulated to a high level between $1 \mathrm{l}$ and $15 \mathrm{hr}$ of sporulation and remained at a high level until $24 \mathrm{hr}$ of sporulation (Fig. 7E,F; Law and Segall 1988). Accumulation of SPS100 transcripts was both delayed and reduced in the sps1/sps1 strain in sporulation medium (Fig. 7E), and SPS101 transcripts failed to accumulate to a significant extent at any time in the mutant strain (Fig. 7F). Rehybridization of the blots of Figure 7 with radioactively labeled $P Y K 1$ DNA confirmed that approximately equal amounts of RNA had been loaded in each lane of the gels (Fig. 7D,G; data not shown). 


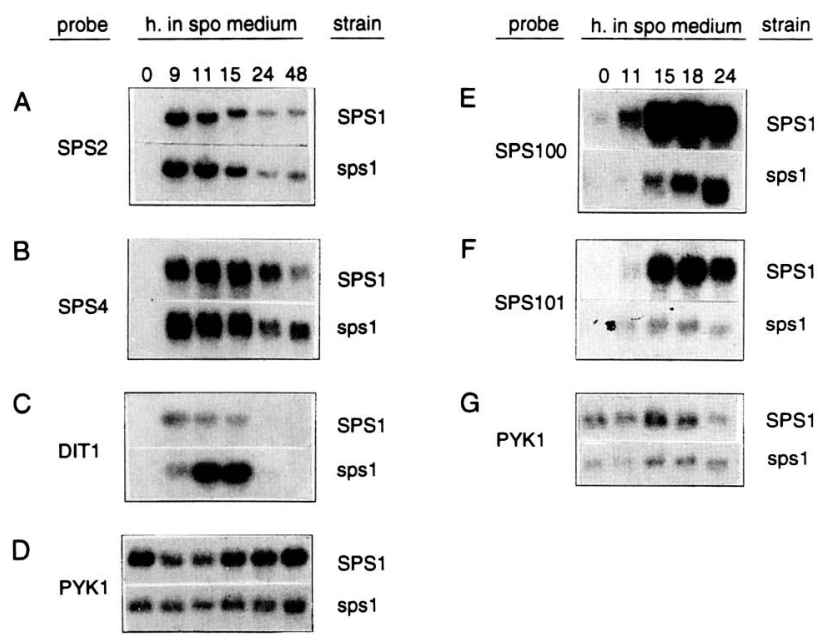

Figure 7. Expression of sporulation-specific genes in SPS1/ SPS1 and sps1/sps1 cells. Accumulation of transcripts was monitored for the following genes: $(A)$ SPS2; $(B) S P S 4 ;(C) D I T 1$; (E) SPS100; $(F)$ SPS101 as denoted in the column titled probe. RNA was purified from wild-type cells (strain LP-HT; denoted SPS1 in the column titled strain) and from sps1/sps1 cells (strain YRL1; denoted sps l in the column titled strain) at the indicated times after transfer to sporulation medium. The RNA was denatured, separated by electrophoresis through a $1.5 \%$ agarose-formaldehyde gel, and transferred to a nylon membrane. The RNA blots were hybridized with the indicated radioactively labeled gene-specific probes (see Materials and methods). After autoradiography, the hybridized DNA was removed and all blots were rehybridized with a radioactively labeled probe containing the $P Y K 1$ gene to test for equal loading of RNA in all lanes. $(D, G)$ The control hybridizations with the $P Y K 1$ probe for the filters of $C$ and $F$, respectively. Only the portions of the autoradiographs that revealed hybridization with the probes are shown.

\section{Discussion}

Mutation of SPS1 blocks spore wall development and late sporulation-specific gene expression

The finding that SPS1 encodes a putative protein kinase prompted us to investigate the role of Sps1 in the sporulation program of $S$. cerevisiae in greater detail. As might be expected from the observation that maximal expression of SPS1 occurs as meiosis is nearing completion, we found that sps1/sps1 cells could complete meiosis I and meiosis II as assayed by DAPI staining of nuclear material. The mutant cells, which did not form spores as assessed by phase-contrast microscopy, were able to reenter the mitotic cycle on transfer to rich medium as has been shown for several other meiotically arrested $\mathrm{mu}$ tants (Davidow and Byers 1984; Shuster and Byers 1989; Bishop et al. 1992; Honigberg et al. 1992; Rose and Holm 1993; Sym et al. 1993; Honigberg and Esposito 1994). The recovery of haploid progeny from $s p s 1$-arrested cells suggested that postmeiotic nuclear compartmentalization had occurred in a portion of the mutant cells. Electron microscopy revealed the formation of prospore-like compartments, usually one or two, in some of the sps1/ sps1 cells. These compartments, which were more variable in size than were wild-type spores, had the appearance of prospores that had been arrested at various stages of development prior to spore wall maturation. The observation that spore-like compartments that were blocked at different stages of development as well as unenveloped nuclei could be found within the same cell suggests some degree of independence in the development of sister spores.

The finding that some sps1/sps1 cells appeared to contain separated nuclei that had not been enveloped by prospore membranes contrasts with the observation that in wild-type cells meiotic nuclear division occurs concomitantly with prospore wall formation (Moens 1971). However, nuclear division occurring independently of spore wall formation has been observed previously in spo1/spo1, spo2/spo2, and spo3/spo3 mutant cells (Moens et al. 1974). Because some sps1/sps1 cells contained more than four compartments, including prospore-like compartments and unenveloped nuclei, it would appear that occasionally only part of a nucleus was encapsulated or that an anucleate spore-like compartment formed. This is reminiscent of the lack of coordination between nuclear division and prospore wall formation seen in spo2 and spo3 diploids (Moens et al. 1974).

The mature wild-type spore wall is multilayered with the two outermost layers being spore specific (Kregervan Rij 1978; Briza et al. 1988, 1990a). The outermost layer, which contains a dityrosine-containing molecule, is deposited over a chitosan-containing layer (Briza et al. $1988,1990 \mathrm{a})$. These two outer layers appeared to be absent from the sps1 spore-like compartments. It should be noted that the absence of these layers alone does not prevent visualization of spores by phase-contrast microscopy (Briza et al. 1990a; Pammer et al. 1992). We therefore infer that there is an additional structural defect in sps1 prospore walls. The chitosan layer appears to be essential for incorporation of dityrosine into the spore wall (Briza et al. 1990b, 1994; Pammer et al. 1992). Because we have found that at least one of the genes required for formation of the dityrosine-containing layer (Briza et al. 1990b, 1994) is expressed in the mutant cells, we therefore suggest that the absence of the chitosan layer might prevent deposition of the dityrosine-containing layer around the sps1 spore-like compartments.

Because the viability of sps1-arrested cells was not as high as was the viability of wild-type sporulating cells, it is possible that completion of meiosis was lethal to some of the mutant cells. The recovery of a population of haploid progeny from sps 1-arrested cells indicates, however, that some of the postmeiotic cells were viable. The origin of the haploid progeny that were derived from sps 1 . arrested cells is unclear. It is possible that a haploid nucleus that failed to be encapsulated in an immature spore migrated into a daughter bud on resumption of growth, as has been shown recently for spo14-arrested cells (Honigberg et al. 1992; Honigberg and Esposito 1994). Another possibility is that the sps1 prospores were released from the ascal sac and began to grow. 
In addition to preventing spore wall maturation, $\mathrm{mu}$ tation of SPS1 also perturbed the pattern of sporulationspecific gene expression during the later portion of the sporulation program. DIT1 transcripts accumulated to a higher level in SPS1 mutant cells than in wild-type cells. Expression of SPS100 was delayed and reduced, and expression of SPS101 was almost undetectable in SPS1 mutant cells. Interestingly, this aberrant pattern of late gene expression is similar to that seen in cells compromised for efficient sporulation attributable to high-copy effects of SPS2 (Percival-Smith and Segall 1987).

\section{Possible targets of the SPS1-encoded protein kinase}

In contemplating a possible role for Sps1 kinase in sporulation, not only do we wish to account for the defect in spore packaging in the mutant cells but also for the observation that the mutant cells are less efficient than are wild-type cells in completing meiosis II. A structure that could contribute both to efficient completion of meiosis and to spore packaging is the spindle pole body. During the second meiotic division, an outer plaque develops as an enlargement of the outer layer of the spindle pole body. Prospore wall formation initiates from this outer plaque (Moens and Rapport 1971; Davidow et al. 1980). A modification to the spindle pole bodies at the end of meiosis I, such as a hypothetical Sps1-dependent phosphorylation event, might contribute to the efficiency of the next round of spindle pole body duplication as well as to outer plaque development. In this scenario, the defect caused by the absence of Spsl would ultimately prevent spore maturation and indirectly prevent activation of late SPS genes.

An alternative explanation for the phenotype of sps1/ sps1 cells is that Sps1-dependent phosphorylation leads to activation of a transcriptional regulator that is responsible for the expression of a set of mid-late sponulationspecific genes. This hypothetical set of SPS1-dependent genes not only would include structural genes required for efficient completion of meiosis II and spore wall maturation but also regulatory gene(s) required to activate expression of late SPS genes such as SPS100. Because $D I T 1$, a mid-late gene required for spore wall maturation, is expressed in the asporogenous sps1/sps1 cells, it is necessary to also invoke an SPS1-independent pathway for expression of some of the mid-late genes involved in spore wall formation. Additionally, the unusually high level of expression of DIT1 in the sps1/sps1 strain suggests that an SPS1-dependent gene might be responsible for turning down expression of DIT1.

The identification of Spsl as a putative protein kinase adds to the growing list of kinases that have been found to play a role in sporulation in S. cerevisiae (for review, see Hoekstra et al. 1991). Entry into meiosis is regulated in part by a decrease in the activity of cAMP-dependent protein kinase in response to nutrient limitation (for review, see Broach 1991). The expression of $I M E 1$, a key regulatory gene required for almost all meiotic gene expression (for review, see Mitchell 1994), is stimulated by $M C K 1$, which encodes a dual specificity kinase (Dailey et al. 1990; Neigeborn and Mitchell 1991). This kinase also plays a role in ascus maturation (Neigeborn and Mitchell 1991) and centromere function (Shero and $\mathrm{Hi}$ eter 1991). The RIM11-encoded kinase is required for Imel to activate expression of IME2 (Mitchell and Bowdish 1992; Smith et al. 1993; Mitchell 1994). Ime2/Smel, which contributes to early meiotic gene expression, is itself a putative protein kinase (Yoshida et al. 1990). Mek1, another meiosis-specific protein kinase homolog, is required for chromosome synapsis and recombination (Rockmill and Roeder 1991). Additionally, the cell cycle kinases $\mathrm{Cdc} 28$ and $\mathrm{Cdc} 7$ and the DNA repair-associated kinase Hrr25 are required for progression through meiosis (for review, see Hoekstra et al. 1991).

\section{A protein kinase cascade regulating spore wall development?}

Four functionally distinct signal transduction pathways that operate via a protein kinase cascade to activate a MAP kinase have been identified in yeast (for review, see Errede and Levin 1993; Neiman 1993; Ammerer 1994; Marshall 1994). The observation that the catalytic domain of Sps1 has $44 \%$ identity with the catalytic domain of Ste20, a member of the MAP kinase pathway involved in response to mating pheromone, suggests the existence of a novel sporulation-specific kinase cascade. Indeed, a sporulation-specific gene, $S M K 1$, encoding a protein with homology to MAP kinases (Krisak et al., this issue) has been identified. The phenotype of $s m k 1 / s m k 1$ cells is strikingly similar to that of sps1/sps1 cells (Krisak et al., this issue). This raises the possibility that Sps1 and Smkl are components of a kinase cascade required to coordinate events involved in spore wall formation.

Ste20 is stimulated by release of the $\beta \gamma$ subunit complex from the heterotrimeric G-protein associated with the membrane-bound pheromone receptor and acts in conjunction with Ste5 to activate Stel1 kinase (Leberer et al. 1992; Ramer and Davis 1993; for review, see Sprague and Thorner 1992). Stell then activates Ste7 kinase (Neiman and Herskowitz 1994), which leads to activation of the MAP kinase homologs Fus 3 and Kss1, which in turn activate the transcription factor Stel2 (for review, see Sprague and Thorner 1992). In contrast to the role of a heterotrimeric G-protein in regulating Ste20 kinase, a Ras-related small GTP-binding protein recently has been shown to activate $\mathrm{p} 65^{\mathrm{PAK}}$, a mammalian relative of Ste20 (Manser et al. 1994). Future experiments will reveal whether the activity of Spsl is regulated solely by transcription, by a member of the G-protein family, or by some other mechanism. Further insight into the putative Sps1/Smkl kinase pathway awaits the identification of other members of the cascade as well as the ultimate target of the pathway.

\section{Materials and methods}

Plasmids

pl8 (Percival-Smith and Segall 1984) contains a 3.7-kb fragment of yeast DNA encompassing the entire SPS1 gene inserted into 
the BamHI site of pBR322. pSPS1-URA3, a replicating yeast plasmid containing the SPS1 gene, was obtained by cloning a 2.3-kb BamHI-XbaI fragment purified from p18 (Percival-Smith and Segall 1986) that had been propagated in a dam ${ }^{-}$strain of Escherichia coli between the corresponding sites of pRS316 (Sikorski and Hieter 1989). pCAN ${ }^{\mathrm{s}} 1-\mathrm{LEU} 2$, used to integrate the $\mathrm{CAN}^{\mathrm{s}} 1$ allele into the yeast genome, contained a $1.8 \mathrm{~kb}$ BamHI-Sall fragment encompassing the $C A N^{s} 1$ gene (Hoffman 1985) cloned between the corresponding sites of pRS306 (Sikorski and Hieter 1989). p18-2 (Percival-Smith and Segall 1986) was used to disrupt the chromosomal SPS1 gene by insertion of URA3 12 codons upstream of the predicted stop codon of SPS1. This plasmid contains a DNA fragment encompassing the URA3 gene inserted into the BglII site at the $3^{\prime}$ end of SPS1 (see Fig. 1). YIp $\Delta S T$, the plasmid used to delete the $5^{\prime}$ end of the chromosomal SPS1 gene, was a derivative of $\mathrm{pRL1}$. $\mathrm{pRL1}$ contained a $2.5-\mathrm{kb}$ BamHI-BgIII fragment from pl8, encompassing most of the SPS1 gene, inserted into the BamHI site of pUC18. YIp $\Delta S T$ was constructed by replacement of the ClaI-EcoRV fragment of pRL1, which spans the 5'-end of the SPS1 gene (see Fig. 1), with an $0.85-\mathrm{kb} B g I I I-B g l I I$ fragment containing the TRP1 gene. In the construction of YIp $\Delta S T$, the ClaI and EcoRV site of $\mathrm{pRL} l$ and the BglII ends of the TRP1-containing fragment were filled in with the Klenow form of DNA polymerase I. $E$. coli strains used for cloning were TG1 (K12 $\Delta$ (lac-pro) supE thi

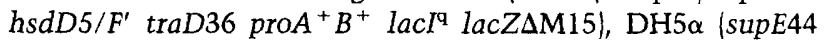

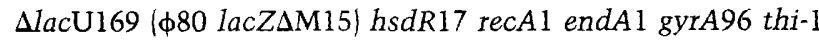
relA1), and W3110dam $3\left(\mathrm{HsdR}^{+}\right.$sup $^{+}$dam $\left.^{-}\right) . \mathrm{CaCl}_{2}$ transformations and recombinant DNA manipulations were carried out as described by Sambrook et al. (1989).

\section{Yeast strains}

All yeast strains used in this study were derived from the isogenic strains W3031A and W3031B /constructed by R. Rothstein) and their derivatives W3031A-H and W3031B-T (Law and Segall 1988) (see Table 1). LP112, provided by S. Lindquist, represents the diploid obtained by mating W3031A and W3031B; LP-HT represents the diploid obtained by mating W3031A-H and W3031B-T. With the exception of LP112, all diploids were obtained by prototrophic selection taking advantage of either chromosomal markers or markers introduced on plasmids for this purpose. The diploid strain YRL1 (MATa/ MAT $\alpha$ sps1::URA3/sps1::URA3) was constructed in three steps. First, we transformed W3031A-H and W3031B-T with p18-2 DNA that had been digested with $B a m H I$ and $X b a I$, as described in Percival-Smith and Segall (1986). Second, insertion of the URA3-containing DNA fragment at the $3^{\prime}$ end of the SPS1 gene was confirmed by Southern blot analysis of genomic DNA from Ura ${ }^{+}$transformants. Finally, a MATa sps1::URA3 strain and a MAT $\alpha$ sps $1:: U R A 3$ strain were mated to give the

Table 1. S. cerevisiae strains

\begin{tabular}{|c|c|}
\hline Strain $^{\mathbf{a}}$ & Genotype \\
\hline W3031A & MATa ade2-1 his3-11,15 leu2-3,115 trp1-1 ura3-1 can $1-100$ \\
\hline W3031B & MAT $\alpha$ ade $2-1$ his $3-11,15$ leu2 $-3,115$ trpl-1 ura3-1 $\operatorname{can}^{\mathrm{r}} 1-100$ \\
\hline W3031A-H & MATa ade2-1 HIS3 leu2-3,115 trpl-1 ura3-1 can $1-100$ \\
\hline W3031B-T & MAT $\alpha$ ade2-1 his3-11,15 leu2-3,115 TRPI ura3-1 can $^{\mathrm{r}} 1-100$ \\
\hline LP112 & 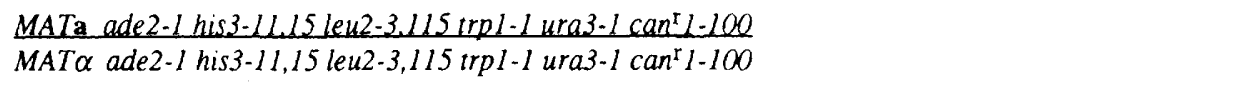 \\
\hline L.P-HT & 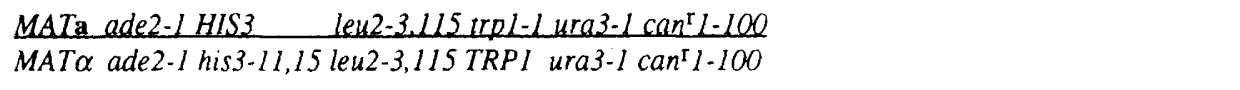 \\
\hline Y6 & MATa ade $2-1$ his 3-11,15 leu2-3,115 trpl-1 ura3-1 can $1-100 \mathrm{cyh}^{\mathrm{r}} 2$ \\
\hline Y7 & MAT a ade2-1 his3-11,15 LEU2 CAN ${ }^{\mathrm{s}} 1 \cdot$ leu2-3,115 trpl-1 ura3-1 $\operatorname{can}^{\mathrm{r}} 1-100$ cyh $^{\mathrm{r}} 2$ \\
\hline Y8 & MATa ade2-I his3-11,15 LEU2 CAN $1 \cdot$ leu2-3,115 trpl-1 ura3-1 can $1-100$ cyh 2 Aspsl::TRP1 \\
\hline Y31 & MAT $\alpha$ ade2-1 his3-11,15 leu2-3,115 trpl-1 ura3-1 can $1-100$ Asps $1:$ TRPI \\
\hline Y26 & 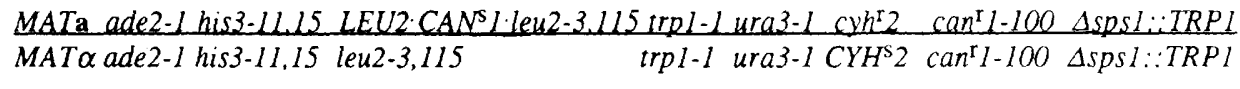 \\
\hline Y30 & 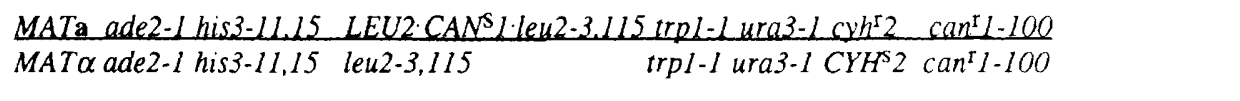 \\
\hline YRLl & 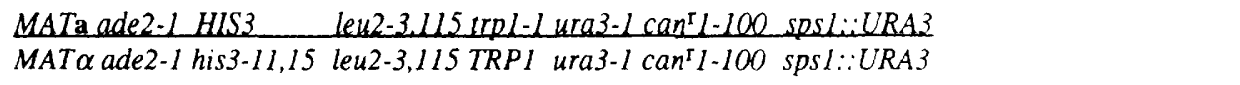 \\
\hline
\end{tabular}

a These strains were generated by the authors, with the exception of W3031A and W3031B (from R. Rothstein) and LP112 (from S. Lindquist). 
diploid strain YRL1. Y8 (MATa 4 sps1::TRP1) and Y31 (MATa $\Delta$ sps1::TRP1) were obtained by transforming W3031B and Y7 (see below), respectively, with YIp $\Delta$ ST that had been digested with BamHI and HindIII. Deletion-substitution of the $5^{\prime}$ end of the chromosomal SPS1 gene with TRP1-containing DNA, to give the allele referred to as $\Delta s p s 1$, was confirmed by Southern blot analysis. We have found that MATa/MAT $\alpha$ sps $1:: U R A 3 /$

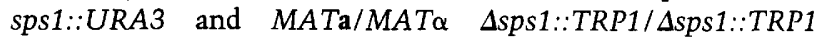
strains behave identically in all our phenotypic and genetic analyses.

Diploid strains heterozygous for $\operatorname{can}^{\mathrm{r}} 1$ and $c y h^{\mathrm{r}} 2$ were obtained as follows. First, a spontaneous cycloheximide-resistant mutant of W3031A, Y6, was isolated as described by Sikorski and Boeke (1991). Strain $Y 7$, a canavanine-sensitive derivative of $\mathrm{Y} 6$, was generated by transforming $\mathrm{Y} 6$ with pCAN ${ }^{\mathrm{s}} 1-\mathrm{LEU} 2$, which had been partially digested with EcoRI. This resulted in the targeting of the plasmid to the leu2 locus giving a $C A N^{\mathrm{s}} 1$ gene flanked by leu2 and LEU2, generating the allele LEU2$C A N^{\mathrm{s}} 1-$ leu2. Replacement of the SPS1 gene of $\mathrm{Y} 7$ with the $\triangle$ sps1::TRP1 allele by integrative transformation generated strain Y8 (see above). After pSPS1-URA3 had been introduced into strain W3031B and into strain Y31, the plasmid-containing W3031B strain was mated with $Y 7$ and the plasmid-containing Y31 strain was mated with Y8. The plasmid provided a URA3 marker for prototrophic selection of diploids and allowed us to confirm that the diploid obtained in the latter cross was able to sporulate efficiently. Diploid strains heterozygous for cyh2 and can1 and lacking pSPS1-URA3, referred to as Y30 (SPS1/SPS1) and Y26 ( $\triangle$ sps $1:: T R P 1 / \Delta s p s 1:: T R P 1)$, were then isolated on 5-fluoro-orotic acid (Boeke et al. 1984).

Yeast transformations were done as recommended by Schiestl and Gietz (1989). Growth and sporulation were as described by Percival-Smith and Segall (1984). In brief, cells were grown in YPD supplemented with $40 \mu \mathrm{g} / \mathrm{ml}$ of adenine or in SD supplemented with required amino acids and bases (Sherman 1991). To induce sporulation, cells were pregrown in YEPA $10.5 \%$ yeast extract, $1 \%$ Bacto-peptone, and $1 \%$ potassium acetate) supplemented with $40 \mu \mathrm{g} / \mathrm{ml}$ of adenine for at least three generations. When the cells had reached a density of $1 \times 10^{7}$ to $2 \times 10^{7}$ cells $/ \mathrm{ml}$, they were washed and transferred to sporulation medium ( $1 \%$ potassium acetate supplemented with required amino acids and bases) at $1 \times 10^{7}$ to $2 \times 10^{7}$ cells $/ \mathrm{ml}$.

\section{Sequencing strategy}

A 2.5-kb BamHI-BglII fragment of p1 8 was subcloned in both orientations in the BamHI site of pUC18. Nucleotide sequence was obtained from restriction endonuclease-generated derivatives of these plasmids by the dideoxy-chain termination method of Sanger et al. (1977) with commercially available primers using double-stranded DNA as template. Both strands of the inserts were sequenced. The last 291 nucleotides of SPS1 have been sequenced previously (Percival-Smith and Segall 1986). The two sequences differ at codon 469; GGA is present in the current sequence and AGA was present in the previous sequence. A protein homology search was performed using the BLAST network service of the National Center for Biotechnology Information. The GenBank accession number for the SPS1 sequence reported in this paper is U13018.

\section{RNA isolation and analysis}

RNA was prepared from yeast and analyzed as described by Percival-Smith and Segall (1984). The probes used in Northern blot analysis to detect various transcripts were as follows: SPS1, a 550-bp ClaI-EcoRV fragment from pSPS1-URA3; HOP1, a 3.0-kb EcoRI-EcoRV fragment from pNH59-2 (Hollingsworth et al. 1990); DIT1, a 1.8-kb HindIII-HindIII fragment from pPB-13 (Briza et al. 1990); PYK1, a 1.0-kb HpaI-HpaI (Burke et al. 1983) fragment from pPYKl01 (provided by Bryan McNeil); SPS2, a $0.8 \cdot \mathrm{kb}$ PstI-HindIII fragment from pl 8 (Percival-Smith and Segall 1986); SPS4, p275 digested with HindIII (Garber and Segall 1986); SPS100, a 750-bp BamHI-NcoI fragment from pE18-B8a (Law and Segall 1988); and SPS101, pC2 digested with EcoRI (Law and Segall 1988). The probes were radioactively labeled using a random priming method (Feinberg and Vogelstein 1983).

\section{DAPI staining}

Approximately $1 \mathrm{ml}$ of cells was harvested and fixed by resuspension in $0.5 \mathrm{ml}$ of a solution containing $50 \%$ ethanol, $1 \mathrm{M}$ sorbitol, and $10 \mathrm{~mm} \mathrm{NaPO}$ (pH 7.2) (Bishop et al. 1992). Slides were pretreated with $1 \%$ polyethyleneimine for $5 \mathrm{~min}$ and rinsed in water. Twenty microliters of fixed cells was placed on the slide and allowed to settle for $30 \mathrm{~min}$. The cells were then rinsed in phosphate-buffered saline (PBS) (Sambrook et al. 1989) prior to being stained for $5 \mathrm{~min}$ with $10 \mu \mathrm{g} / \mathrm{ml}$ of DAPI in PBS. After rinsing the slides in PBS, $10 \mu$ l of mounting solution $10.8 \%$ propylgallate, $90 \%$ glycerol) was added, coverslips were put on, and the slides were sandwiched between paper towels and weighted for $30 \mathrm{~min}$ prior to being viewed with fluorescent optics.

\section{Assays for resumption of mitotic growth and for} haploid progeny derived from spsl-arrested cells

Resumption of growth was assessed using cells that had been pregrown in YEPA to a concentration of $1 \times 10^{7}$ to $2 \times 10^{7}$ cells/ $\mathrm{ml}$ and then transferred to sporulation medium. At various times, samples of cells were diluted and plated on YPD. To determine the efficiency of haploidization, we examined the uncovering of recessive drug-resistant alleles. In these experiments SPS1/SPS1 CAN $N^{\mathrm{s}} 1 / \mathrm{can}^{\mathrm{r}} 1 C^{\mathrm{C}} \mathrm{CH}^{\mathrm{s}} 2 / \mathrm{cyh}^{\mathrm{r}} 2$ and sps $1 /$ sps 1 $C A N^{\mathrm{s}} 1 / \mathrm{can}^{\mathrm{r}} 1 \mathrm{CYH}^{\mathrm{s}} 2 / \mathrm{cyh}^{\mathrm{r}} 2$ cells were pregrown in YEPA, transferred to sporulation medium at a concentration of $1 \times 10^{7}$ to $2 \times 10^{7} \mathrm{cells} / \mathrm{ml}$, incubated for $21 \mathrm{hr}$ in sporulation medium, diluted, and plated on YPD. After a $24 \mathrm{hr}$ incubation, the resultant colonies were patched on YPD, incubated for $24 \mathrm{hr}$, and replica plated to $\mathrm{SD}$ containing the appropriate supplements and either $10 \mu \mathrm{g} / \mathrm{ml}$ of cycloheximide or $60 \mu \mathrm{g} / \mathrm{ml}$ of canavanine.

For FACS analyses, wild-type and mutant cells were incubated in sporulation medium for $21 \mathrm{hr}$, diluted in YPD, and grown for $21 \mathrm{hr}$. Approximately $10^{7}$ cells were washed and fixed in $70 \%$ ethanol. Fixed cells were resuspended in $50 \mathrm{~mm}$ sodium citrate at $\mathrm{pH} 7.4$, sonicated briefly, and treated with $0.25 \mathrm{mg} / \mathrm{ml}$ of RNase A for $1 \mathrm{hr}$ at $50^{\circ} \mathrm{C}$. Cells were then stained with 8 $\mu \mathrm{g} / \mathrm{ml}$ of propidium iodide in citrate buffer for $30 \mathrm{~min}$ at $24^{\circ} \mathrm{C}$ in the dark, treated with $0.2 \mathrm{mg} / \mathrm{ml}$ of proteinase $\mathrm{K}$ for $1 \mathrm{hr}$ at $50^{\circ} \mathrm{C}$, and sonicated to disperse clumps. Fluorescence was measured using a Becton Dickinson FACScan and analyzed with LYSYS II software. No gating was used, and 20,000 cells were examined in each experiment.

\section{Electron microscopy}

Cells from strains $\mathrm{Y} 30$ and Y26 that had been in sporulation medium for $21 \mathrm{hr}$ were centrifuged, washed in $\mathrm{H}_{2} \mathrm{O}$, and prepared for electron microscopy using procedures modified from Hayat (1970) and Briza et al. (1988). In brief, cells were fixed overnight in a solution containing 3\% glutaraldehyde, $3 \%$ acrolein, and $0.1 \mathrm{M}$ sodium cacodylate. Samples were washed and 
postfixed in $1.5 \%$ potassium permanganate for $1 \mathrm{hr}$ at $4^{\circ} \mathrm{C}$, washed again, and fixed with $1 \%$ osmium tetroxide in veronyl acetate buffer for $30 \mathrm{~min}$ at $24^{\circ} \mathrm{C}$. Samples were embedded in warm agar and dehydrated through a graded series of ethanol, and were then embedded in Spurr resin. Thin sections were stained with saturated uranyl acetate and Reynold's lead citrate and examined on a Philips 300 electron microscope.

\section{Acknowledgments}

We thank Edward Winter and Saul Honigberg for very helpful discussions during the course of this work and for communicating results prior to publication. We thank Saul Honigberg, Anthony Percival-Smith, Paul Sadowski, and Edward Winter for their valuable comments on our manuscript. We thank Randall Willis for technical assistance, Aaron Mitchell for plasmid DNAs, Brenda Andrews, Andrew Spence, and David Williams for assistance with microscopy, and Cheryl Smith of the Flow Cytometry Facility of the Department of Immunology, University of Toronto for assistance with FACS analysis. This work was supported by a Medical Research Council (Canada) grant (MA-6826) to J.S.

The publication costs of this article were defrayed in part by payment of page charges. This article must therefore be hereby marked "advertisement" in accordance with 18 USC section 1734 solely to indicate this fact.

\section{References}

Altschul, S.F., W. Gish, W. Miller, E.W. Myers, and D.L. Lipman. 1990. Basic local alignment search tool. J. Mol. Biol. 215: 403-410.

Ammerer, G. 1994. Sex, stress and integrity: The importance of MAP kinases in yeast. Curr. Opin. Genet. Dev. 4: 90-95.

Atcheson, C.L., B. DiDomenico, S. Frackman, R.E. Esposito, and R.T. Elder. 1987. Isolation, DNA sequence, and regulation of a meiosis-specific eukaryotic recombination gene. Proc. Natl. Acad. Sci. 84: 8035-8039.

Beckett, A., R.F. Illingworth, and A.H. Rose. 1973. Ascospore wall development in Saccharomyces cerevisiae. J. Bacteriol. 113: 1054-1067.

Bishop, D.K., D. Park, L. Xu, and N. Kleckner. 1992. DMC1: A meiosis-specific yeast homolog of $E$. coli recA required for recombination, synaptonemal complex formation, and cell cycle progression. Cell 69: 439-456.

Boeke, J.D., F. LaCroute, and G.R. Fink. 1984. A positive selection for mutants lacking orotidine-5'-phosphate decarboxylase activity in yeast: 5-Fluoro-orotic acid resistance. Mol. Gen. Genet. 197: 345-346.

Briza, P., A. Ellinger, G. Winkler, and M. Breitenbach. 1988. Chemical composition of the yeast ascospore wall. The second outer layer consists of chitosan. J. Biol. Chem. 263: 11569-11574.

- 1990a. Characterization of a DL-dityrosine-containing macromolecule from yeast ascospore walls. J. Biol. Chem. 265: 15118-15123.

Briza, P., M. Breitenbach, A. Ellinger, and J. Segall. 1990b. Isolation of two developmentally regulated genes involved in spore wall maturation in Saccharomyces cerevisiae. Genes \& Dev. 4: 1775-1789.

Briza, P., M. Eckerstorfer, and M. Breitenbach. 1994. The sporulation-specific enzymes encoded by the DIT1 and DIT2 genes catalyze a two step reaction leading to a soluble-LLdityrosine-containing precursor of the yeast spore wall. Proc. Natl. Acad. Sci. 91: 4524-4528.
Broach, J.R. 1991. RAS genes in Saccharomyces cerevisiae: Signal transduction in search of a pathway. Trends Genet. 7: 28-33.

Burke, R.L., P. Tekamp-Olson, and R. Najarian. 1983. The isolation, characterization, and sequence of the pyruvate kinase gene of Saccharomyces cerevisiae. J. Biol. Chem. 258: 21932201.

Byers, B. 1981. Cytology of the yeast life cycle (ed. J.N. Strathern, E.W. Jones, and J.R. Broach), pp. 59-96. In The molecular biology of the yeast Saccharomyces: Life cycle and inheritance. Cold Spring Harbor Laboratory, Cold Spring Harbor, New York.

Clancy, M.J., B. Buten-Magee, D.J. Straight, A.L. Kennedy, R.M. Partridge, and P.T. Magee. 1983. Isolation of genes expressed preferentially during sporulation in the yeast Saccharomyces cerevisiae. Proc. Natl. Acad. Sci. 80: 3000-3004.

Coe, J.G.S., L.E. Murray, C.J. Kennedy, and I.W. Dawes. 1992. Isolation and characterization of sporulation-specific promoters in the yeast Saccharomyces cerevisiae. Mol. Microbiol. 6: 75-81.

Dailey, D., G.L. Schieven, M.Y. Lim, H. Marquardt, T. Gilmore, J. Thorner, and G.S. Martin. 1990. Novel yeast protein kinase (YPK1 gene product) is a 40-kilodalton phosphotyrosyl protein associated with protein-tyrosine kinase activity. Mol. Cell. Biol. 10: 6244-6256.

Davidow, L.S. and B. Byers. 1984. Enhanced gene conversion and postmeiotic segregation in pachytene-arrested Saccharomyces cerevisiae. Genetics 106: 165-183.

Davidow, L.S., L. Goetsch, and B. Byers. 1980. Preferential occurrence of nonsister spores in two-spored asci of Saccharomyces cerevisiae: Evidence for regulation of spore wall formation by the spindle pole body. Genetics 94: 581-595.

Errede, B. and D.E. Levin. 1993. A conserved kinase cascade for MAP kinase activation in yeast. Curr. Opin. Cell Biol. 5: 254-260.

Esposito, M.S. and R.E. Esposito. 1969. The genetic control of sporulation in Saccharomyces. I. The isolation of temperature-sensitive sporulation-deficient mutants. Genetics 61: 79-89.

1974. Genes controlling meiosis and spore formation in yeast. Genetics 78: 215-225.

Esposito, R.E. and S. Klapholz. 1981. Meiosis and ascospore development (ed. J.N. Strathern, E.W. Jones, and J.R. Broach), pp.211-287. In The molecular biology of the yeast Saccharomyces: Life cycle and inheritance. Cold Spring Harbor Laboratory, Cold Spring Harbor, New York.

Feinberg, A.P. and B. Vogelstein. 1983. A technique for radiolabeling DNA restriction endonuclease fragments to high specific activity. Anal. Biochem. 132: 6-13.

Garber, A.T. and J. Segall. 1986. The SPS4 gene of Saccharomyces cerevisiae encodes a major sporulation-specific mRNA. Mol. Cell. Biol. 6: 4478-4485.

Gottlin-Ninfa, E. and D.B. Kaback. 1986. Isolation and functional analysis of sporulation-induced transcribed sequences from Saccharomyces cerevisiae. Mol. Cell. Biol. 6: 21852197.

Guth, E., T. Hashimoto, and S.F. Conti. 1972. Morphogenesis of ascospores in Saccharomyces cerevisiae. I. Bacteriol. 109: 869-880.

Hanks, S.K. 1991. Eukaryotic protein kinases. Curr. Opin Struct. Biol. 1: 369-383.

Hanks, S.K. and A.M. Quinn. 1991. Protein kinase catalytic domain sequence database: Identification of conserved features of primary structure and classification of family members. Methods Enzymol. 200: 38-62.

Hanks, S.K., A.M. Quinn, and T. Hunter. 1988. The protein 
kinase family: Conserved features and deduced phylogeny of the catalytic domains. Science 241: 42-52.

Hayat, M.A. 1970. Principles and techniques of electron microscopy, Vol. I. p. 339. Van Nostrand Reinhold Co., New York.

Hoekstra, M.F., A.J. Demaggio, and N. Dhillon. 1991. Genetically identified protein kinases in yeast. II: DNA metabolism and meiosis. Trends Genet. 7: 293-297.

Hoffman, W. 1985. Characterization of the CAN1 locus in Saccharomyces cerevisiae. J. Biol. Chem. 260: 11831-11837.

Hollingsworth, N.M. and B. Byers. 1989. HOP1: A yeast meiotic pairing gene. Genetics 121: 445-462.

Hollingsworth, N.M., L. Goetsch, and B. Byers. 1990. The HOP1 gene encodes a meiosis-specific component of yeast chromosomes. Cell 61: 73-84.

Honigberg, S.M. and R.E. Esposito. 1994. Reversal of cell determination in yeast meiosis: Post-commitment arrest allows return to mitotic growth. Proc. Natl. Acad. Sci. 91: 65596563.

Honigberg, S.M., C. Conicella, and R.E. Esposito. 1992. Commitment to meiosis in Saccharomyces cerevisiae: involvement of the SPO14 gene. Genetics 130: 703-716.

Illingworth, R.F., A.H. Rose, and A. Beckett. 1973. Changes in the lipid composition and fine structure of Saccharomyces cerevisiae during ascus formation. J. Bacteriol. 113: 373386.

Kallal, L.A., M. Bhattacharyya, S.N. Grove, R.E. Iannacone, T.A. Pugh, D.A. Primerano, and M.J. Clancy. 1990. Functional analysis of the sporulation-specific SPR6 gene of Saccharomyces cerevisiae. Curr. Genet. 18: 293-301.

Kao, G., D.G. Mannix, B.L. Holaway, M.C. Finn, A.E. Bonny, and M.J. Clancy. 1989. Dependence of inessential late gene expression on early meiotic events in Saccharomyces cerevisiae. Mol. \& Gen. Genet. 215: 490-500.

Katohda, S., K. Konno, Y. Sasaki, K. Suzuki, and S. Sakomoto. 1984. Isolation and composition of the spore wall of Saccharomyces cerevisiae. Agr. Biol. Chem. 48: 895-901.

Katz, P., G. Whalen, and J.H. Kehrl. 1994. Differential expression of a novel protein kinase in human B lymphocytes: Preferential localization in the germinal center. $J$. Biol. Chem. 269: 16802-16809.

Kreger-van Rij, N.J.W. 1978. Electron microscopy of germinating ascospores of Saccharomyces cerevisiae. Arch. Microbiol. 117: 73-77.

Krisak, L., R. Strich, R.S. Winters, P. Hall, M.J. Mallory, D. Kreitzer, R.S. Tuan, and E. Winter. 1994. SMK1, a developmentally regulated MAP kinase, is required for spore wall assembly in Saccharomyces cerevisiae. Genes \& Dev. (this issue).

Law, D.T.S. and I. Segall. 1988. The SPS100 gene of Saccharomyces cerevisiae is activated late in the sporulation process and contributes to spore wall maturation. Mol. Cell. Biol. 8: 912-922.

Leberer, E., D. Dignard, D. Harcus, D.Y. Thomas, and M. Whiteway. 1992. The protein kinase homologue Ste20p is required to link the yeast pheromone response G-protein $\beta \gamma$ subunits to downstream signalling components. $E M B O J$. 11: 48154824.

Lynn, R.R. and P.T. Magee. 1970. Development of the spore wall during ascospore formation in Saccharomyces cerevisiae. J. Cell Biol. 44: 688-692.

Malone, R.E., S. Bullard, M. Hermiston, R. Rieger, M. Cool, and A. Galbraith. 1991. Isolation of mutants defective in early steps of meiotic recombination in the yeast Saccharomyces cerevisiae. Genetics 128: 79-88.

Manser, E., T. Leung, H. Salihuddin, Z.-S. Zhao, and L. Lim.
1994. A brain serine/threonine protein kinase activated by Cdc42 and Racl. Nature 367: 40-46.

Marshall, C.J. 1994. MAP kinase kinase kinase, MAP kinase kinase and MAP kinase. Curr. Opin. Genet. Dev. 4: 82-89.

Mitchell, A.P. 1994. Control of meiotic gene expression in Saccharomyces cerevisiae. Microbiol. Rev. 58: 56-70.

Mitchell, A.P. and K.S. Bowdish. 1992. Selection for early meiotic mutants in yeast. Genetics 131: 65-72.

Mitchell, A.P., S.E. Driscoll, and H.E. Smith. 1990. Positive control of sponlation-specific genes by the IME1 and IME2 products in Saccharomyces cerevisiae. Mol. Cell. Biol. 10: $2104-2110$.

Moens, P.B. 1971. Fine structure of ascospore development in the yeast Saccharomyces cerevisiae. Can. I. Microbiol. 17: 507-510.

Moens, P.B. and E. Rapport. 1971. Spindles, spindle plaques, and meiosis in the yeast, Saccharomyces cerevisiae. I. Cell. Biol. 50: 344-361.

Moens, P.B., R.E. Esposito, and M.S. Esposito. 1974. Aberrant nuclear behavior at meiosis and anucleate spore formation by sporulation-deficient (SPO) mutants of Saccharomyces cerevisiae. Exp. Cell Res. 83: 166-174.

Muthukumar, G., S. Suhung, P.T. Magee, R.D. Jewell, and D.A. Primerano. 1993. The Saccharomyces cerevisiae SPR1 gene encodes a sporulation-specific exo-1,3- $\beta$-glucanase which contributes to spore thermoresistance. I. Bacteriol. 175: 386-394.

Neigeborn, L. and A.P. Mitchell. 1991. The yeast MCK1 gene encodes a protein kinase homolog that activates early meiotic gene expression. Genes \& Dev. 5: 533-548.

Neiman, A.M. 1993. Conservation and reiteration of a kinase cascade. Trends Genet. 9: 390-394.

Neiman, A.M., and I. Herskowitz. 1994. Reconstitution of a yeast protein kinase cascade in vitro: Activation of the yeast MEK homologue STE7 by STE11. Proc. Natl. Acad. Sci. 91: 3398-3402.

Pammer, M., P. Briza, A. Ellinger, T. Schuster, R. Stucka, H. Feldmann, and M. Breitenbach. 1992. DIT101 (CSD2, $C A L 1$ ), a cell cycle-regulated yeast gene required for synthesis of chitin in cell walls and chitosan in spore walls. Yeast 8: 1089-1099.

Percival-Smith, A. and J. Segall. 1984. Isolation of DNA sequences preferentially expressed during sporulation in Saccharomyces cerevisiae. Mol. Cell. Biol. 4: 142-150.

- 1986. Characterization and mutational analysis of a cluster of three genes expressed preferentially during sporulation of Saccharomyces cerevisiae. Mol. Cell. Biol. 6: 24432451.

- 1987. Increased copy number of the $5^{\prime}$ end of the SPS2 gene inhibits sporulation of Saccharomyces cerevisiae. Mol Cell. Biol. 7: 2484-2490.

Pittman, D., W. Lu, and R.E. Malone. 1993. Genetic and molecular analysis of REC114, an early meiotic recombination gene in yeast. Curr. Genet. 23: 295-304.

Ramer, S.W. and R.W. Davis. 1993. A dominant truncation allele identifies a gene, STE20, that encodes a putative kinase necessary for mating in Saccharomyces cerevisiae. Proc. Natl. Acad. Sci. 90: 452-456.

Rockmill, B. and G.S. Roeder. 1988, RED1: A yeast gene required for the segregation of chromosomes during the reductional division of meiosis. Proc. Natl. Acad. Sci. 85: 60576061.

- 1991. A meiosis-specific protein kinase homolog required for chromosome synapsis and recombination. Genes \& Dev. 5: 2392-2404.

Rose, D. and C. Holm. 1993. Meiosis-specific arrest revealed in 
DNA topoisomerase II mutants. Mol. Cell. Biol. 13: 34453455.

Sambrook, J., E.F. Fritsch, and T. Maniatis. 1989. Molecular cloning: A laboratory manual. Cold Spring Harbor Laboratory Press, Cold Spring Harbor, New York.

Sanger, F., S. Nicklen, and A.R. Coulson. 1977. DNA sequencing with chain-terminating inhibitors. Proc. Natl. Acad. Sci. 74: 5463-5467.

Schiestl, R.H. and R.D. Gietz. 1989. High efficiency transformation of intact yeast cells using single stranded nucleic acids as a carrier. Curr. Genet. 16: 339-346.

Sherman, F. 1991. Getting started with yeast. Methods Enzymol. 194: 3-21.

Shero, J.H. and P. Hieter. 1991. A suppressor of a centromere DNA mutation encodes a putative protein kinase (MCK1). Genes \& Dev. 5: 549-560.

Shuster, E.O. and B. Byers. 1989. Pachytene arrest and other meiotic effects of the start mutations in Saccharomyces cerevisiae. Genetics 123: 29-43.

Sikorski, R.S. and J.D. Boeke. 1991. In vitro mutagenesis and plasmid shuffling: From cloned gene to mutant yeast. Methods Enzymol. 194: 302-318.

Sikorski, R.S. and P. Hieter. 1989. A system of shuttle vectors and yeast host strains designed for efficient manipulation of DNA in Saccharomyces cerevisiae. Genetics 122: 19-27.

Smith, H.E., S.S. Su, L. Neigeborn, S.E. Driscoll, and A.P. Mitchell. 1990. Role of IME1 expression in regulation of meiosis in Saccharomyces cerevisiae. Mol. Cell. Biol. 10: 6103-6113.

Smith, H.E., S.E. Driscoll, R.A.L. Sia, H.E. Yuan, and A.P. Mitchell. 1993. Genetic evidence for transcriptional activation by the yeast IME1 gene product. Genetics 133: 775-784.

Sprague, G.F. Jr., and J.W. Thorner. 1992. Pheromone response and signal transduction during the mating process of Saccharomyces cerevisiae (ed. E.W. Jones, J.R. Pringle, and J.R. Broach), pp. 657-744. In The molecular and cellular biology of the yeast Saccharomyces: Gene expression. Cold Spring Harbor Laboratory, Cold Spring Harbor, New York.

Sym, M., J. Engebrecht, and G.S. Roeder. 1993. ZIP1 is a synaptonemal complex protein required for meiotic chromosome synapsis. Cell 72: 365-378.

Thompson, E.A. and G.S. Roeder. 1989. Expression and DNA sequence of RED1, a gene required for meiosis I chromosome segregation in yeast. Mol. \& Gen. Genet. 218: 293-301.

Tsuboi, M. 1983. The isolation and genetic analysis of sporulation-deficient mutants in Saccharomyces cerevisiae. Mol. \& Gen. Genet. 191: 17-21.

Yoshida, M., H. Kawaguchi, Y. Sakata, K.I. Kominami, M. Hirano, H. Shima, R. Akada, and I. Yamashita. 1990. Initiation of meiosis and sporulation in Saccharomyces cerevisiae requires a novel protein kinase homologue. Mol. \& Gen. Genet. 221: 176-186. 


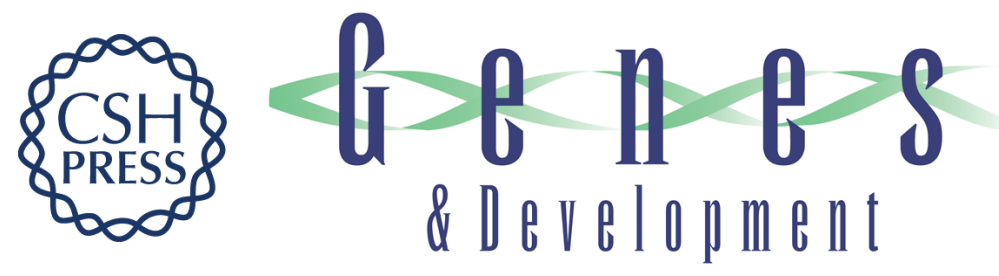

\section{Mutation of the SPS1-encoded protein kinase of Saccharomyces cerevisiae leads to defects in transcription and morphology during spore formation.}

H Friesen, R Lunz, S Doyle, et al.

Genes Dev. 1994, 8:

Access the most recent version at doi:10.1101/gad.8.18.2162

References This article cites 77 articles, 46 of which can be accessed free at:

http://genesdev.cshlp.org/content/8/18/2162.full.html\#ref-list-1

License

Email Alerting

Service

Receive free email alerts when new articles cite this article - sign up in the box at the top right corner of the article or click here.

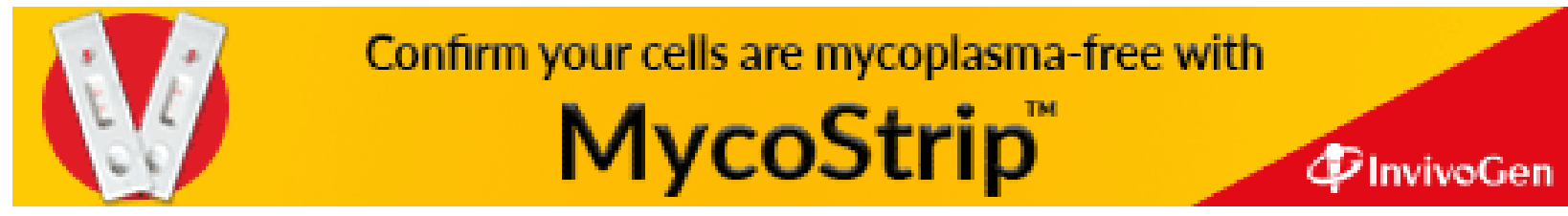

